\title{
Saliva glycoproteins bind to Spike protein of SARS-CoV-2
}

Dapeng Zhou ${ }^{1 * \#}$, Chenghao $\mathrm{Wu}^{1 \#}$

${ }^{1}$ Tongji University School of Medicine, Shanghai, 200092, China

*Corresponding author:

dapengzhoulab@tongji.edu.cn

\# Contributed equally to this work 


\begin{abstract}
We analyzed the affinity-proteomics data of saliva absorbed to plate-bound Spike protein of SARS-CoV-2, and identified major virus-binding proteins as MUC7, MUC5B, DMBT1, and neutrophil defensins. Furthermore, we found that saliva from healthy donors inhibited the binding of Spike-protein-specific polyclonal antibodies to Spike antigen. These data suggest that the Spike protein's glycoprotein-binding domains (GBD) may be targeted to block virus adherence or entry of SARS-CoV-2.
\end{abstract}

Key words: SARS-CoV2; corona virus; affinity proteomics; glycoproteins; glycoprotein-binding domains

\title{
Introduction
}

Saliva is a major route of spreading for COVID-19 pandemic [1]. SARS-CoV-2 has been found in saliva of infected patients, with a virus titer of up to $10^{8}$ PFU per ml. Multiple protein components such as MUC5B, defensins and DMBT1 have been reported to bind to viruses [2-4]. DMBT1 binds to gp120 of HIV-1 virus and mediates the viral infection in macrophages at mucosal site [5].

In this study, we performed affinity-proteomics analysis on saliva using recombinant SARSCoV-2 Spike protein. We also examined the inhibition effect of saliva on polyclonal antibodies raised against Spike protein of SARS-CoV-2.

\section{Results}




\section{Spike protein of SARS-CoV-2 binds to multiple saliva proteins}

A total of 138 proteins with ion abundance higher than $10^{7}$ were absorbed by plate-bound Spikeprotein from 3 volunteers (Table 1 and supplemental Tables 1-3). The proteins with highest ion abundance were MUC7, MUC5B, DMBT1, and neutrophil defensins. Most high-abundance saliva proteins in previous proteomics studies were not present in our samples absorbed by Spike protein [6-7], indicating that most saliva proteins do not bind to Spike protein. SDS-PAGE analysis of saliva samples before and after Spike protein absorption clearly showed that most salvia proteins were unbound and washed away, as visualized by silver staining (Supplemental Figure 1).

\section{Saliva proteins inhibit the binding of polyclonal antibodies to Spike protein}

To test whether saliva proteins inhibit the binding of polyclonal antibodies specific to Spike protein of SARS-CoV-2, we collected saliva of healthy donors of different gender and age groups (study protocol: 2020tjdx055, Tongji University). The inhibition rate was defined as the percentage of maximum inhibition in serial diluted antibody sample pooled from Spike proteinvaccinated mice. We found above $50 \%$ inhibition rate in 13 of the 22 donors (Figure 1). No significant difference were found among different age or gender groups. The maximum inhibition was observed at the sera dilution fold of 1:6075 to 1:54675 (Table 2 and Supplemental Figure 2), indicating that the vaccination-induced antibodies may overcome the inhibitory effect of saliva very efficiently.

\section{Discussion}


Saliva proteins are known to contain virus-binding proteins and be involved in viral pathogenesis. Many viruses bind to saliva through recognizing glycan ligands attached to host mucins [8-12]. Sialic acid-containing glycoproteins are one of the critical receptors for cellular entry by several corona viruses including Transmissible gastroenteritis virus (TGEV) [13], porcine epidemic diarrhea virus (PEDV) [14], HCoV-OC43 and MERS [15-17]. It remains to be studied whether Spike protein of SARS-CoV-2 binds to glycans attached to host glycoproteins which we have discovered (Table 1).

Sugar binding domain of PEDV-CoV and MERS-CoV Spike protein is considered as important for the critical entry functions [13, 18]. Four monoclonal antibodies (MAbs 56, 60, 63, and 72) targeting the sialic acid-binding domain could neutralize GDU strain of PEDV-CoV virus at 0.015 to $0.039 \mu \mathrm{g} / \mathrm{ml}$ of concentration [13]. Passive immunization of mice with a mAb $1.10 \mathrm{f} 3$ which target sialic acid-binding domain of MERS-CoV resulted in 40\% protection from mortality following MERS-CoV infection [18]. In our study, we observed the maximum inhibition rate of saliva protein in competing with the antibody binding to Spike protein at the titer of 1:6075 to 1:54675. The exact nature of the domains that bind to saliva glycoproteins and whether they are targets are neutralizing antibodies remain to be studied. Ongoing studies are being focused to isolate potential neutralizing antibodies in SARS-CoV-2 infected or vaccinated individuals that may block the Spike protein's glycoprotein-binding domains (GBD).

In summary, our study clearly identified saliva glycoproteins as binders of Spike protein of SARS-CoV-2. Glycoprotein-binding domains of SARS-CoV-2 virus are potential targets for the development of antibody therapeutics and vaccines. 


\section{Methods}

\section{Affinity proteomics by recombinant Spike protein}

Recombinant insect cell-derived Spike proteins for SARS-CoV-2 (GenBank Accession Number: MN908947) was prepared as described [19]. A plate-bound assay was used to purify saliva proteins which bind to Spike protein. 96-well Clear Flat Bottom Polystyrene High Bind Microplate (Corning) was coated by $1 \mathrm{mg} / \mathrm{ml}$ Spike protein in $\mathrm{PBS}$ at $4^{\circ} \mathrm{C}$ for overnight, and washed five times with $0.05 \%$ Tween in PBS (every time for 2 minutes using a mini shaker). The $\mathrm{S}$ protein-coated plates were blocked with $1 \%$ bovine serum albumin (Sigma) at $37^{\circ} \mathrm{C}$ for one hour, and washed five times with $0.05 \%$ Tween in PBS. Saliva were added at $50 \mu 1$ per well and 96 wells were used to absorb saliva from every donor. The saliva samples were incubated for one hour at $37^{\circ} \mathrm{C}$ to bind plate-bound $\mathrm{S}$ protein. Unbound saliva proteins were discarded and the plates were washed for five times with $0.05 \%$ Tween in PBS. Saliva proteins bound to S protein were released by adding $0.1 \mathrm{M}$ Glycine- $\mathrm{HCl}(\mathrm{pH} 2.5)$. The eluted proteins were neutralized by 50 $\mathrm{mM}$ Tris buffer ( $\mathrm{pH} 8.0)$ and desalted by Pierce concentrator (30K, MWCO, $0.5 \mathrm{ml})$. The proteins samples were reduced and digested by trypsin (Promega) as described (19). The trypsindigested peptides were desalted with mono-Spin C18 column (GL Sciences). The desalted peptide mixture were analyzed by LC-MS-MS as described using an Easy-nLC 1000 system (Thermo Scientific, San Jose, CA) and orbitrap analyzer (Q Exactive mass spectrometer, Thermo Scientific, San Jose, CA).

\section{Preparation of anti-sera to Spike protein}

All animal studies were approved by the animal care and use committee of Tongji University. All experiments were carried in SPF housing facilities. C57/BL6 strain of mice (male, 8 weeks 
old) were immunized by recombinant $\mathrm{S}$ protein with polyI:C as adjuvant [20]. $5 \mu \mathrm{g}$ of $\mathrm{S}$ protein mixed with $50 \mu \mathrm{g}$ of polyI:C adjuvant (Yisheng Biopharma, Beijing) were injected per mouse intramuscularly [20]. Two vaccination schedule were tested. In Schedule A, mice were immunized at days 0, 7 and 16. In Schedule B, mice were immunized at days 0, 3 and 7. Sera from immunized mice were collected by tail vein bleeding, and anti-S protein antibody titer was measured by ELISA. $50 \mu \mathrm{l}$ of $1 \mu \mathrm{g} / \mathrm{ml}$ S protein in PBS was bound to 96 -well Clear Flat Bottom Polystyrene High Bind Microplate (Corning) at $4^{\circ} \mathrm{C}$ for overnight, and washed five times with $0.05 \%$ Tween in PBS (every time for 2 minutes using a mini shaker). The S proteincoated plates were blocked with $100 \mu \mathrm{l} \quad 1 \%$ bovine serum albumin at $37^{\circ} \mathrm{C}$ for one hour, and washed five times with $0.05 \%$ Tween in PBS, followed by incubation with $50 \mu$ serially diluted sera for one hour. The plates were washed for five times, and the anti-S protein mouse IgG was visualized by a secondary antibody (goat anti-mouse IgG, Southern Biotech) followed by colorimetric detection. One percent bovine serum albumin in PBS was used as blank to determine the cutoff value.

\section{Measurement of inhibition rate of saliva on antibodies generated against $S$ protein}

Saliva of healthy donors of different gender and age groups were collected to test their inhibition rate on pooled mouse sera containing polyclonal anti-Spike protein antibodies (study protocol: 2020tjdx055, Tongji University). Saliva samples were directly used to block the plate-bound Spike protein for one hour before ELISA experiment as below: $50 \mu \mathrm{l}$ of $1 \mu \mathrm{g} / \mathrm{ml}$ S protein was bound to 96-well Clear Flat Bottom Polystyrene High Bind Microplate (Corning) at $4^{\circ} \mathrm{C}$ for overnight, and washed five times with $0.05 \%$ Tween in PBS (every time for 2 minutes using a mini shaker). The S protein-coated plates were blocked with $100 \mu 11 \%$ bovine serum albumin at 
$37^{\circ} \mathrm{C}$ for one hour, and washed five times with $0.05 \%$ Tween in PBS. The plates were incubated with $50 \mu \mathrm{l}$ saliva per well at $37^{\circ} \mathrm{C}$ for one hour, and washed for five times. Pooled sera from vaccinated mice (with anti-S antibody titer of 1:54675) were serially diluted and added, and antiS protein mouse IgG was visualized by a secondary antibody (goat anti-mouse IgG, Southern Biotech) followed by colorimetric detection. The inhibition rate was determined as the percentage inhibition of absorbance at OD450, at the antibody dilution that showed maximum rate of inhibition.

\section{Acknowledgement}

We thank Xiaoxu Tian and Chao Peng of the Mass Spectrometry System at the National Facility for Protein Science in Shanghai (NFPS), Zhangjiang Lab, China for providing technical support and assistance in data collection and analysis. This work was supported by National Natural Science Foundation of China grant 31870972, National Key Research and Development Plan grant 2017YFA0505901, and Fundamental Research Funds for the Central Universities 22120180201. All these sponsors have no roles in the study design, or the collection, analysis, and interpretation of data.

\section{Conflict of interest disclosures}

The authors declare no conflict of interest.

\section{Author contributions}


Dapeng Zhou designed this study. Dapeng Zhou and Chenghao Wu contributed to the collection, analysis and interpretation of data. Dapeng Zhou wrote the manuscript. All authors read and approved the final manuscript.

\section{Reference:}

1. To KK, Tsang OT, Leung WS, Tam AR, Wu TC, Lung DC, Yip CC, Cai JP, Chan JM, Chik TS, Lau DP, Choi CY, Chen LL, Chan WM, Chan KH, Ip JD, Ng AC, Poon RW, Luo CT, Cheng VC, Chan JF, Hung IF, Chen Z, Chen H, Yuen KY. Temporal profiles of viral load in posterior oropharyngeal saliva samples and serum antibody responses during infection by SARS-CoV-2: an observational cohort study. Lancet Infect Dis. 2020 Mar 23. pii: S1473-3099(20)30196-1.

2. Malamud D, Abrams WR, Barber CA, Weissman D, Rehtanz M, Golub E. Antiviral activities in human saliva. Adv Dent Res. 2011 Apr;23(1):34-7.

3. De Smet K, Contreras R. Human antimicrobial peptides: defensins, cathelicidins and histatins. Biotechnol Lett. 2005 Sep;27(18):1337-47. Review.

4. White MR, Helmerhorst EJ, Ligtenberg A, Karpel M, Tecle T, Siqueira WL, Oppenheim FG, Hartshorn KL. Multiple components contribute to ability of saliva to inhibit influenza viruses. Oral Microbiol Immunol. 2009 Feb;24(1):18-24

5. Crombie R, Silverstein RL, MacLow C, Pearce SF, Nachman RL, Laurence J. Identification of a CD36related thrombospondin 1-binding domain in HIV-1 envelope glycoprotein gp120: relationship to HIV-1specific inhibitory factors in human saliva. J Exp Med. 1998 Jan 5;187(1):25-35.

6. Loo JA, Yan W, Ramachandran P, and Wong DT. Comparative Human Salivary and Plasma Proteomes. J Dent Res. 2010 Oct; 89(10): 1016-1023.

7. Yan W, Apweiler R, Balgley BM, Boontheung P, Bundy JL, Cargile BJ, Cole S, Fang X, GonzalezBegne M, Griffin TJ, Hagen F, Hu S, Wolinsky LE, Lee CS, Malamud D, Melvin JE, Menon R, Mueller M, Qiao R, Rhodus NL, Sevinsky JR, States D, Stephenson JL, Than S, Yates JR, Yu W, Xie H, Xie Y, Omenn 
GS, Loo JA, Wong DT. Systematic comparison of the human saliva and plasma proteomes. Proteomics Clin Appl. 2009 Jan 1;3(1):116-134.

8. Tan M, Cui L, Huo X, Xia M, Shi F, Zeng X, Huang P, Zhong W, Li W, Xu K, Chen L, Zhou M, Jiang

X. Saliva as a source of reagent to study human susceptibility to avian influenza H7N9 virus infection. Emerg Microbes Infect. 2018 Sep 19;7(1):156.

9. Marionneau S, Airaud F, Bovin NV, Le Pendu J, Ruvoën-Clouet N. Influence of the combined ABO, FUT2, and FUT3 polymorphism on susceptibility to Norwalk virus attachment. J Infect Dis. 2005 Sep $15 ; 192(6): 1071-7$.

10. Liu Y, Huang P, Jiang B, Tan M, Morrow AL, Jiang X. Poly-LacNAc as an age-specific ligand for rotavirus P[11] in neonates and infants. PLoS One. 2013 Nov 11;8(11):e78113.

11. Zhang XF, Huang Q, Long Y, Jiang X, Zhang T, Tan M, Zhang QL, Huang ZY, Li YH, Ding YQ, Hu GF, Tang S, Dai YC. An outbreak caused by GII.17 norovirus with a wide spectrum of HBGA-associated susceptibility. Sci Rep. 2015 Dec 7;5:17687.

12. Suptawiwat O, Ruangrung K, Boonarkart C, Puthavathana P, Maneechotesuwan K, Charngkaew K, Chomanee N, Auewarakul P. Microparticle and anti-influenza activity in human respiratory secretion. PLoS One. 2017 Aug 23;12(8):e0183717.

13. Li C, Li W, Lucio de Esesarte E, Guo H, van den Elzen P, Aarts E, van den Born E, Rottier PJM, Bosch BJ. Cell Attachment Domains of the Porcine Epidemic Diarrhea Virus Spike Protein Are Key Targets of Neutralizing Antibodies. J Virol. 2017 May 26;91(12). pii: e00273-17.

14. Yuan P, Yang Z, Song H, Wang K, Yang Y, Xie L, Huang S, Liu J, Ran L, Song Z. Three Main Inducers of Alphacoronavirus Infection of Enterocytes: Sialic Acid, Proteases, and Low pH. Intervirology. 2018;61(2):53-63.

15. Park YJ, Walls AC, Wang Z, Sauer MM, Li W, Tortorici MA, Bosch BJ, DiMaio F, Veesler D. Structures of MERS-CoV spike glycoprotein in complex with sialoside attachment receptors. Nat Struct Mol Biol. 2019 Dec;26(12):1151-1157. 
16. Tortorici MA, Walls AC, Lang Y, Wang C, Li Z, Koerhuis D, Boons GJ, Bosch BJ, Rey FA, de Groot RJ, Veesler D. Structural basis for human coronavirus attachment to sialic acid receptors. Nat Struct Mol Biol. 2019 Jun;26(6):481-489.

17. Li W, Hulswit RJG, Widjaja I, Raj VS, McBride R, Peng W, Widagdo W, Tortorici MA, van Dieren B, Lang Y, van Lent JWM, Paulson JC, de Haan CAM, de Groot RJ, van Kuppeveld FJM, Haagmans BL, Bosch BJ. Identification of sialic acid-binding function for the Middle East respiratory syndrome coronavirus spike glycoprotein. Proc Natl Acad Sci U S A. 2017 Oct 3;114(40):E8508-E8517.

18. Widjaja I, Wang C, van Haperen R, Gutiérrez-Álvarez J, van Dieren B, Okba NMA, Raj VS, Li W, Fernandez-Delgado R, Grosveld F, van Kuppeveld FJM, Haagmans BL, Enjuanes L, Drabek D, Bosch BJ. Towards a solution to MERS: protective human monoclonal antibodies targeting different domains and functions of the MERS-coronavirus spike glycoprotein. Emerg Microbes Infect. 2019;8(1):516-530.

19. Zhou, D.; Qi, R.; Zhang, W.; Tian, X.; Peng, C. Identification of 22 N-glycosites on Spike Glycoprotein of SARS-CoV-2 and Accessible Surface Glycopeptide Motifs: Implications on Vaccination and Antibody Therapeutics. Preprints 2020, 2020020381 (doi: 10.20944/preprints202002.0381.v2).

20. Kalimuddin S, Wijaya L, Chan YFZ, Wong AWL, Oh HML, Wang LF, Kassim JA, Zhao J, Shi Z, Low JG. A phase II randomized study to determine the safety and immunogenicity of the novel PIKA rabies vaccine containing the PIKA adjuvant using an accelerated regimen. Vaccine. 2017 Dec 18;35(51):7127-7132. 
Figure legends:

Figure 1. Inhibition rate of saliva from healthy donors on the binding of Spike protein to polyclonal antibodies. Saliva samples were directly used to block the plate-bound Spike protein for one hour before ELISA experiment. The inhibition rate was determined as the percentage inhibition of absorbance at OD450, at the antibody dilution that showed maximum rate of inhibition (Table 2, Supplemental Figure 2).

\section{Supplemental Online Materials}

Supplemental Table 1: List of proteins absorbed by plate-bound Spike protein from saliva of volunteer A.

Supplemental Table 2: List of proteins absorbed by plate-bound Spike protein from saliva of volunteer $B$.

Supplemental Table 3: List of proteins absorbed by plate-bound Spike protein from saliva of volunteer $\mathbf{C}$.

Supplemental Figure 1: SDS-PAGE of saliva proteins from healthy volunteers before and after absorption by plate-bound Spike protein of SARS-CoV-2.

Supplemental Figure 2: Comparison of ELISA data with and without saliva inhibition. Mouse sera containing polyclonal antibodies to Spike protein of SARS-CoV-2 were pooled and 
titrated by ELISA. Saliva from healthy donors were added to serially-diluted antibodies to examine the inhibition rate. 
Table 1: Most abundant proteins absorbed to Spike protein to SARS-CoV-2 as measured by mass spectrometry

\begin{tabular}{|c|c|c|c|c|}
\hline Protein & Full name & & Ion abundan & \\
\hline (UNIPROT ID) & & Volunteer A & Volunteer B & Volunteer C \\
\hline $\begin{array}{l}\text { MUC7 } \\
\text { (Q8TAX7) }\end{array}$ & Mucin-7 & $2.72 \mathrm{E}+07$ & $1.64 \mathrm{E}+09$ & $1.20 \mathrm{E}+09$ \\
\hline $\begin{array}{l}\text { MUC5B } \\
\text { (Q9HC84) }\end{array}$ & Mucin-5B & $1.00 \mathrm{E}+08$ & $1.44 \mathrm{E}+07$ & $1.83 \mathrm{E}+07$ \\
\hline $\begin{array}{l}\text { DMBT1* }^{*} \\
\text { (Q9UGM3) }\end{array}$ & Deleted in malignant brain tumors 1 protein & $1.45 \mathrm{E}+09$ & $1.43 \mathrm{E}+09$ & $7.48 \mathrm{E}+07$ \\
\hline $\begin{array}{l}\text { NR1F3/ RORG } \\
\text { (P51449) }\end{array}$ & $\begin{array}{l}\text { Nuclear receptor ROR-gamma (Nuclear } \\
\text { receptor RZR-gamma) }\end{array}$ & $4.82 \mathrm{E}+08$ & $1.71 \mathrm{E}+08$ & $5.48 \mathrm{E}+07$ \\
\hline $\begin{array}{l}\text { DEFA1 } \\
\text { (P59665) }\end{array}$ & $\begin{array}{l}\text { Neutrophil defensin } 1 \text { (Defensin, alpha 1) } \\
\text { (HNP-1, HP-1, HP1) }\end{array}$ & ND & $3.42 \mathrm{E}+08$ & $1.07 \mathrm{E}+08$ \\
\hline $\begin{array}{l}\text { DEFA3 } \\
\text { (P59666) }\end{array}$ & $\begin{array}{l}\text { Neutrophil defensin } 3 \text { (Defensin, alpha 3) } \\
\text { (HNP-3, HP-3, HP3) }\end{array}$ & $7.93 \mathrm{E}+08$ & $3.42 \mathrm{E}+08$ & $1.07 \mathrm{E}+08$ \\
\hline $\begin{array}{l}\text { ZG16B* } \\
\text { (Q96DA0) }\end{array}$ & Zymogen granule protein 16 homolog B & $7.88 \mathrm{E}+07$ & $2.72 \mathrm{E}+08$ & $1.68 \mathrm{E}+08$ \\
\hline $\begin{array}{l}\text { CTSG } \\
\text { (P08311) }\end{array}$ & Cathepsin G & $1.06 \mathrm{E}+08$ & $1.48 \mathrm{E}+08$ & $1.96 \mathrm{E}+07$ \\
\hline $\begin{array}{l}\text { EECP } \\
\text { (G8H6I3) }\end{array}$ & Endocrine and exocrine protein & $3.94 \mathrm{E}+07$ & ND & $8.38 \mathrm{E}+07$ \\
\hline $\begin{array}{l}\text { PIGR } \\
(\mathrm{P} 01833)\end{array}$ & $\begin{array}{l}\text { Polymeric immunoglobulin receptor, PIgR, } \\
\text { Poly-Ig receptor }\end{array}$ & $1.01 \mathrm{E}+08$ & $3.43 \mathrm{E}+07$ & $3.50 \mathrm{E}+06$ \\
\hline $\begin{array}{l}\text { JCHAIN* }^{*} \\
\text { (P01591) }\end{array}$ & Immunoglobulin J chain & $6.48 \mathrm{E}+07$ & $4.66 \mathrm{E}+07$ & $6.10 \mathrm{E}+06$ \\
\hline $\begin{array}{l}\text { HIST1H4H/ } \\
\text { HIST1H4L/ } \\
\text { HIST1H4A } \\
\text { (P62805) }\end{array}$ & Histone $\mathrm{H} 4$ & $6.57 \mathrm{E}+07$ & $5.58 \mathrm{E}+07$ & $9.06 \mathrm{E}+07$ \\
\hline
\end{tabular}


Table 2. Maximum inhibition rate of saliva on antibody-binding to Spike protein of SARSCoV2 and the antibody titer that maximum inhibition was observed.

\begin{tabular}{|c|c|c|c|c|}
\hline Donor ID & $\begin{array}{l}\text { Inhibition } \\
\text { rate }\end{array}$ & $\begin{array}{l}\text { Serum Antibody } \\
\text { Titer }\end{array}$ & Age & Gender \\
\hline 1 & $52.8 \%$ & $1: 18225$ & 23 & $\mathrm{M}$ \\
\hline 2 & $0.0 \%$ & ND & 24 & $\mathrm{M}$ \\
\hline 3 & $7.8 \%$ & $1: 6075$ & 24 & $\mathrm{M}$ \\
\hline 4 & $95.2 \%$ & $1: 6075$ & 25 & $\mathrm{~F}$ \\
\hline 5 & $72.4 \%$ & $1: 6075$ & 26 & $\mathrm{~F}$ \\
\hline 6 & $16.8 \%$ & $1: 6075$ & 26 & $\mathrm{~F}$ \\
\hline 7 & $21.4 \%$ & $1: 54675$ & 26 & $\mathrm{~F}$ \\
\hline 8 & $79.3 \%$ & $1: 6075$ & 29 & $\mathrm{~F}$ \\
\hline 9 & $60.5 \%$ & $1: 6075$ & 30 & $\mathrm{~F}$ \\
\hline 10 & $58.2 \%$ & $1: 18225$ & 38 & $\mathrm{M}$ \\
\hline 11 & $74.4 \%$ & $1: 6075$ & 39 & $\mathrm{~F}$ \\
\hline 12 & $84.5 \%$ & $1: 6075$ & 42 & $\mathrm{M}$ \\
\hline 13 & $3.8 \%$ & $1: 18225$ & 46 & $\mathrm{M}$ \\
\hline 14 & $73.8 \%$ & $1: 18225$ & 50 & $\mathrm{~F}$ \\
\hline 15 & $13.9 \%$ & $1: 6075$ & 51 & $\mathrm{~F}$ \\
\hline 16 & $72.5 \%$ & $1: 6075$ & 56 & $\mathrm{M}$ \\
\hline 17 & $3.8 \%$ & $1: 6075$ & 60 & $\mathrm{M}$ \\
\hline 18 & $83.0 \%$ & $1: 6075$ & 62 & $\mathrm{M}$ \\
\hline 19 & $63.7 \%$ & $1: 6075$ & 68 & $\mathrm{M}$ \\
\hline 20 & $43.7 \%$ & $1: 18225$ & 70 & $\mathrm{~F}$ \\
\hline 21 & $0.0 \%$ & ND & 78 & $\mathrm{M}$ \\
\hline 22 & $66.7 \%$ & $1: 6075$ & 82 & $\mathrm{~F}$ \\
\hline
\end{tabular}

ND: no inhibition was observed at any dilution of antibody 
Zhou et al., Figure 1
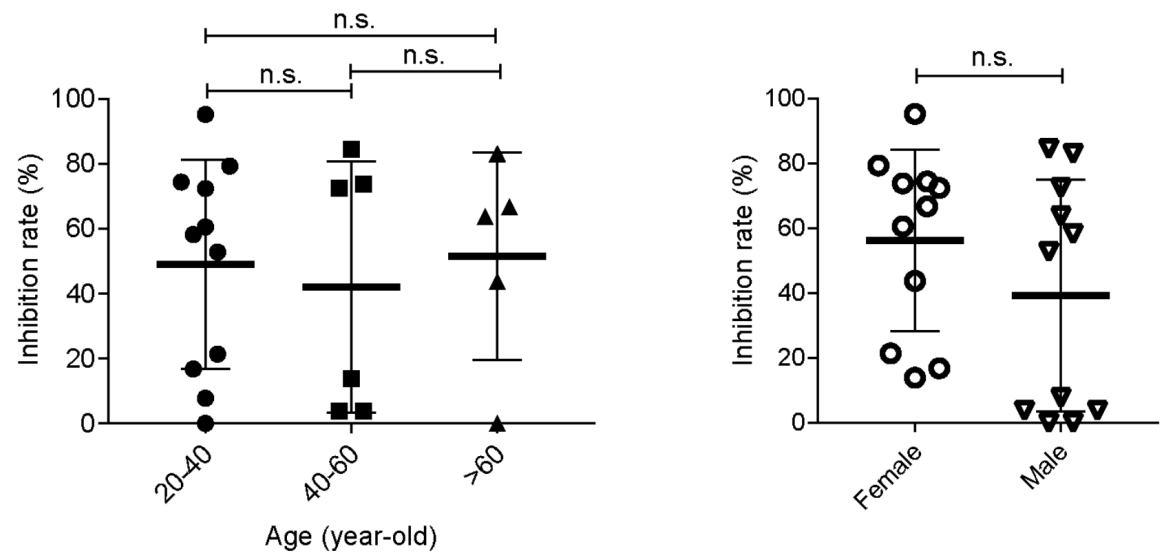